\title{
26. A MÖSSBAUER STUDY OF OCEANIC SEDIMENTS FROM SITE 612, DEEP SEA DRILLING PROJECT LEG 951
}

\author{
Yoshitaka Minai, Department of Chemistry, The University of Tokyo \\ Yuji Nakamura, Laboratory for Earthquake Chemistry, The University of Tokyo \\ and \\ Takeshi Tominaga, Department of Chemistry, The University of Tokyo ${ }^{2}$
}

\begin{abstract}
${ }^{57} \mathrm{Fe}$ Mössbauer spectra of 15 oceanic sediment samples collected from Site 612 (Deep Sea Drilling Project Leg 95) were recorded. These spectra showed that most of the iron in the sediments was present as high-spin, paramagnetic $\mathrm{Fe}^{2+}$ and $\mathrm{Fe}^{3+}$. The ferrous iron was mainly distributed in terrigenous clays and biogenic carbonates. The variation of the Mössbauer parameters for $\mathrm{Fe}^{2+}$ with sub-bottom depth suggests that the main $\mathrm{Fe}^{2+}$-bearing component changed with geologic time. The amount of iron in each iron-bearing phase as estimated from the corresponding peak areas in the spectra also changed with depth. These variations in the Mössbauer parameters and peak areas are correlated with lithologic changes in the sediment column.
\end{abstract}

\section{INTRODUCTION}

Mössbauer spectroscopy is a useful means of obtaining information about the chemical states of iron, tin, and other Mössbauer elements in solids. From the spectra of these elements we can determine the elements' oxidation state, coordination number, spin state, magnetic properties, site symmetry, lattice dynamics, and other structural information. Mössbauer spectroscopy has been used in mineralogical, petrological, and geochemical studies, and most of these applications concern the $14.4 \mathrm{keV}$ ${ }^{57} \mathrm{Fe}$ Mössbauer effect. Earlier studies on silicate minerals (Bancroft et al., 1967, 1968) demonstrated the applicability of this technique to the investigation of the oxidation states and site population of iron and the identification of iron-bearing minerals. Mössbauer spectroscopy can also be applied to characterize more complicated geological materials, such as multiphase assemblages, for mineralogical identification, determination of the $\mathrm{Fe}^{3+} / \mathrm{Fe}^{2+}$ ratio, and the semiquantitative analysis of iron distribution in each mineral and lattice site (Bancroft, 1973). Recent advances in the application of Mössbauer spectroscopy to geological materials have been summarized in several reviews (Bancroft, 1973; Tominaga and Minai, 1984; Bowen and Weed, 1984).

Several previous studies have considered the ${ }^{57} \mathrm{Fe}$ Mössbauer spectroscopy of oceanic sediments. Herzenberg (1970) measured the Mössbauer spectra of a red clay from the Atlantic and a metalliferous sediment from the Red Sea. The former spectrum was composed of high-spin $\mathrm{Fe}^{2+}$, paramagnetic $\mathrm{Fe}^{3+}$, and weak magnetic component $\left(\mathrm{Fe}^{\mathrm{M}}\right)$ envelopes; the latter included $\mathrm{Fe}^{3+}$ absorp-

\footnotetext{
${ }^{1}$ Poag, C. W., Watts, A. B., et al., Init. Repts. DSDP, 95: Washington (U.S. Govt. Printing Office).

2 Addresses: (Minai, Tominaga) Department of Chemistry, Faculty of Science, The University of Tokyo, Hongo, Tokyo, Japan; (Nakamura) Laboratory for Earthquake Chemistry, Faculty of Science, The University of Tokyo, Hongo, Tokyo, Japan.
}

tion with superparamagnetic relaxation, which was ascribed to microcrystalline goethite. Minai et al. (1981) analyzed 20 deep sea sediment samples from the Pacific that were collected by piston coring. Although the spectra were similar to those of the Atlantic sediment previously reported (Herzenberg, 1970), the relative peak area of each component varied with the sampling location in the Pacific. Such regional variation was also reported by Thijs et al. (1981) for deep sea sediments from five areas in the Pacific.

Deep sea sediments usually contain microcrystalline or amorphous particles that cannot be identified by means of microscopic observation or even X-ray diffraction, the conventional method of mineralogical sediment study. Magnetic susceptibility measurement is useful for characterizing the iron contained as magnetic components in the sediments, but the information is limited to the magnetic components, and most of the iron is present as high-spin $\mathrm{Fe}^{2+}$ and paramagnetic $\mathrm{Fe}^{3+}$ in the sediments (Herzenberg, 1970; Minai et al., 1981; Thijs et al., 1981). Thus, Mössbauer spectroscopy is the only quantitative method that obtains information regarding the chemical state of iron in all the iron-bearing components in solids.

Earlier studies (Herzenberg, 1970; Minai et al., 1981; Thijs et al., 1981) suggested that the Mössbauer technique can also play a significant role in the study of iron geochemistry in sediments. Thus, the Mössbauer data elucidate the behavior of iron in the ocean and on the ocean floor. Minai et al. (1981) suggested that the regional variation in the Mössbauer spectra of the Pacific sediments reflects changes in the mixing ratios of terrigenous, biogenic, and hydrogenous materials. Quantitative analysis of each iron-bearing component will provide us with a great deal of information about the iron geochemistry of oceanic sediments.

We used the Mössbauer technique to investigate the chemical state of iron in the sediments recovered from Site 612 (DSDP Leg 95). Our specific objectives were to 
clarify (1) the variation in the distribution of iron among iron-bearing phases throughout the sediment column and (2) the correlation of iron distribution to lithologic variation and geological events.

\section{SAMPLES STUDIED}

From Site 612, which is located on the middle continental slope along the New Jersey Transect $\left(38^{\circ} 49.21^{\prime} \mathrm{N}\right.$; $72^{\circ} 46.43^{\prime} \mathrm{W}$ ), a $675.3-\mathrm{m}$ section was obtained at a water depth of $1404 \mathrm{~m}$. Sediment age ranged from Pleistocene to Campanian. Five lithologic units were recognized in the recovered sediment, and sea level, sedimentation rate, and the influx of terrigenous and biogenic components evidently varied during deposition (Site 612 chapter, this volume).

\section{EXPERIMENTAL METHODS}

Fifteen sediment samples from Site 612 were air dried at room temperature and finely pulverized for Mössbauer measurement. The sampling positions in the core are listed in Table 1 . About $200 \mathrm{mg}$ of each sample were sealed in a $2-\mathrm{cm}^{2}$ sample holder. The total carbonate in these samples was determined on board ship. Total iron was determined by neutron activation analysis. These data are presented in Table 2, together with sample descriptions. Mössbauer spectra were recorded at $293 \mathrm{~K}$ using 2-to- $10 \mathrm{mCi}^{57} \mathrm{Co}(\mathrm{Rh})$ sources with three combinations of different Mössbauer spectrometers and multichannel analyzers: Shimadzu MEG-2 spectrometer with Northern NS-500 analyzer; an Austin Science S-600 spectrometer with an Ino-tec IT-5200 analyzer; and an Elscint MDF-N-5 spectrometer with a Canberra Series 35 analyzer. The velocity scale was calibrated with $\alpha$-iron. Background counts ranged from $5 \times 10^{5}$ to $2 \times 10^{6}$ per channel. To obtain the Mössbauer parameters (isomer shift [I. S.], quadrupole splitting [Q. S.], internal magnetic field $[\mathrm{H}]$, and line width [W]) and relative peak areas, the spectra were fit to Lorentzian curves by a least-squares method, using the $\mathrm{M}-200 / 280 \mathrm{H}$ computer at the Computer Center at The University of Tokyo. The program used was originally written in ALGOL by Duke and Gibb (1967); it was rewritten by Dr. M. Takeda in FORTRAN. The linewidth and intensity of both component peaks of each quadrupole doublet were constrained to be equal during the fitting procedure. The isomer shift is given as the shift relative to the center of the $\alpha-\mathrm{Fe}$ sextet.

\section{RESULTS AND DISCUSSION}

Selected Mössbauer spectra of the sediments from Site 612 are shown in Figures 1 to 4 . The calculated Mössbauer parameters and relative peak areas are summarized in Table 3. Most spectra were composed of at least

Table 1. Sediment samples collected from Site 612 for Mössbauer measurement.

\begin{tabular}{|c|c|c|c|c|}
\hline $\begin{array}{l}\text { Sample } \\
\text { number }\end{array}$ & $\begin{array}{l}\text { Core-Section- } \\
\text { interval }(\mathrm{cm})\end{array}$ & $\begin{array}{l}\text { Sub-bottom } \\
\text { depth (m) }\end{array}$ & $\begin{array}{l}\text { Lithologic } \\
\text { unit }\end{array}$ & Age \\
\hline 1 & $2-1,75-77$ & 5.56 & IA & upper Pleistocene \\
\hline 13 & $8-3,70-73$ & 55.81 & IA & upper Pliocene \\
\hline 16 & $10-2,70-73$ & 70.91 & IA & Pliocene \\
\hline 22 & $13-2,70-73$ & 100.01 & IB & upper Miocene \\
\hline 30 & $17-2,70-73$ & 138.41 & II & uppermost Eocene \\
\hline 33 & $18-4,70-73$ & 150.91 & II & upper Eocene \\
\hline 50 & $28-2,55-57$ & 243.46 & II & middle Eocene \\
\hline 51 & $28-4,75-77$ & 246.66 & II & middle Eocene \\
\hline 64 & $36-4,70-73$ & 323.71 & II/III & middle Eocene \\
\hline 68 & $39-2,70-73$ & 349.51 & III & lower Eocene \\
\hline 82 & $45-2,75-77$ & 407.46 & III & lower Eocene \\
\hline 100 & $55-2,70-73$ & 504.21 & III & lower Eocene \\
\hline 111 & $62-4,80-82$ & 574.31 & IV & Maestrichtian \\
\hline 119 & $67-4,70-73$ & 622.51 & IV & Maestrichtian \\
\hline 124 & $70-3,70-73$ & 649.91 & v & Campanian \\
\hline
\end{tabular}

Table 2. Lithologic description of the samples and their total carbonate and iron contents.

\begin{tabular}{|c|c|c|c|}
\hline $\begin{array}{l}\text { Sample } \\
\text { number }\end{array}$ & Lithologic description & $\begin{array}{c}\text { Carbonate } \\
\text { content }(\%)\end{array}$ & $\begin{array}{c}\mathrm{Fe} \\
\text { content }(\%)\end{array}$ \\
\hline 1 & Dark gray mud & 3 & 3.58 \\
\hline 13 & $\begin{array}{l}\text { Dark gray mud thoroughly mixed } \\
\text { with glauconitic sand }\end{array}$ & 0 & \\
\hline 16 & $\begin{array}{l}\text { Dark gray mud with layers of } \\
\text { olive gray sand }\end{array}$ & 1 & 12.72 \\
\hline 22 & $\begin{array}{l}\text { Olive gray mud with burrows } \\
\text { filled with glauconitic sand }\end{array}$ & 1 & 12.76 \\
\hline 30 & $\begin{array}{l}\text { Siliceous foraminiferal nanno- } \\
\text { fossil ooze }\end{array}$ & 40 & \\
\hline 33 & $\begin{array}{l}\text { Siliceous foraminiferal nanno- } \\
\text { fossil ooze }\end{array}$ & 45 & 1.57 \\
\hline 50 & Siliceous nannofossil chalk & 42 & \\
\hline 51 & Siliceous nannofossil chalk & 39 & 1.17 \\
\hline 64 & Siliceous nannofossil chalk & 49 & 0.57 \\
\hline 68 & Siliceous nannofossil chalk & 42 & 0.60 \\
\hline 82 & Siliceous nannofossil chalk & 44 & 1.04 \\
\hline 100 & Siliceous nannofossil chalk & 50 & 1.16 \\
\hline 111 & $\begin{array}{l}\text { Marly nannofossil foraminiferal } \\
\text { chalk }\end{array}$ & 49 & 1.69 \\
\hline 119 & $\begin{array}{l}\text { Marly nannofossil foraminiferal } \\
\text { chalk }\end{array}$ & 50 & 1.73 \\
\hline 124 & $\begin{array}{l}\text { Black foraminiferal nannofossil } \\
\text { shale }\end{array}$ & 14 & 3.11 \\
\hline
\end{tabular}

two quadrupole doublets. Isomer shifts for high-spin $\mathrm{Fe}^{2+}$ range from 0.8 to $1.5 \mathrm{~mm} / \mathrm{s}$, and those for highspin $\mathrm{Fe}^{3+}$ range from 0.2 to $0.55 \mathrm{~mm} / \mathrm{s}$, respectively (Greenwood and Gibb, 1971). A comparison of the observed Mössbauer isomer shifts with these reported values leads us to ascribe the observed absorptions to highspin $\mathrm{Fe}^{2+}$ and high-spin $\mathrm{Fe}^{3+}$.

The Mössbauer spectrum of Sample 1 (Fig. 1) is exceptional in that it is composed not only of these two quadrupole doublets but also of a sextet due to magnetic hyperfine structure (MHFS). This structure is due to the Zeeman splitting of the excited and ground states for the Mössbauer transition and is caused by a magnetic field at the Mössbauer nucleus. The spectra of ferro-, ferri-, and antiferromagnetic materials have a MHFS similar to that found in many iron-based hydroxides, oxyhydroxides, and oxides. A comparison of internal magnetic field in Sample 1 (Table 3) to the values reported for those materials leads us to ascribe this component to $\mathrm{Fe}^{3+}$ in hematite or maghemite. Oceanic sediments may contain titanomagnetite and/or titanomaghemite, which is formed from the oxidation of titanomagnetite. These Ti-bearing iron-oxide systems were investigated with Mössbauer spectroscopy by Watt et al. (1973) and Jensen et al. (1973), and the parameters reported in those investigations for such oxides agree with our values in Sample 1. The MHFS for Sample 1 can probably be ascribed to titanomaghemite. Although this component cannot be observed in the other spectra, a small amount of iron (under about $5 \%$ of total iron) appears to contribute to the magnetism of all the sediments.

The Mössbauer parameters of the $\mathrm{Fe}^{2+}$ and $\mathrm{Fe}^{3+}$ varied with sub-bottom depth and the lithology of the sample. The kinds of iron-bearing materials change with the depth of the sample. Thus, we should present Mössbauer results separately for each lithologic unit. However, we must point out that the Mössbauer parameters obtained 


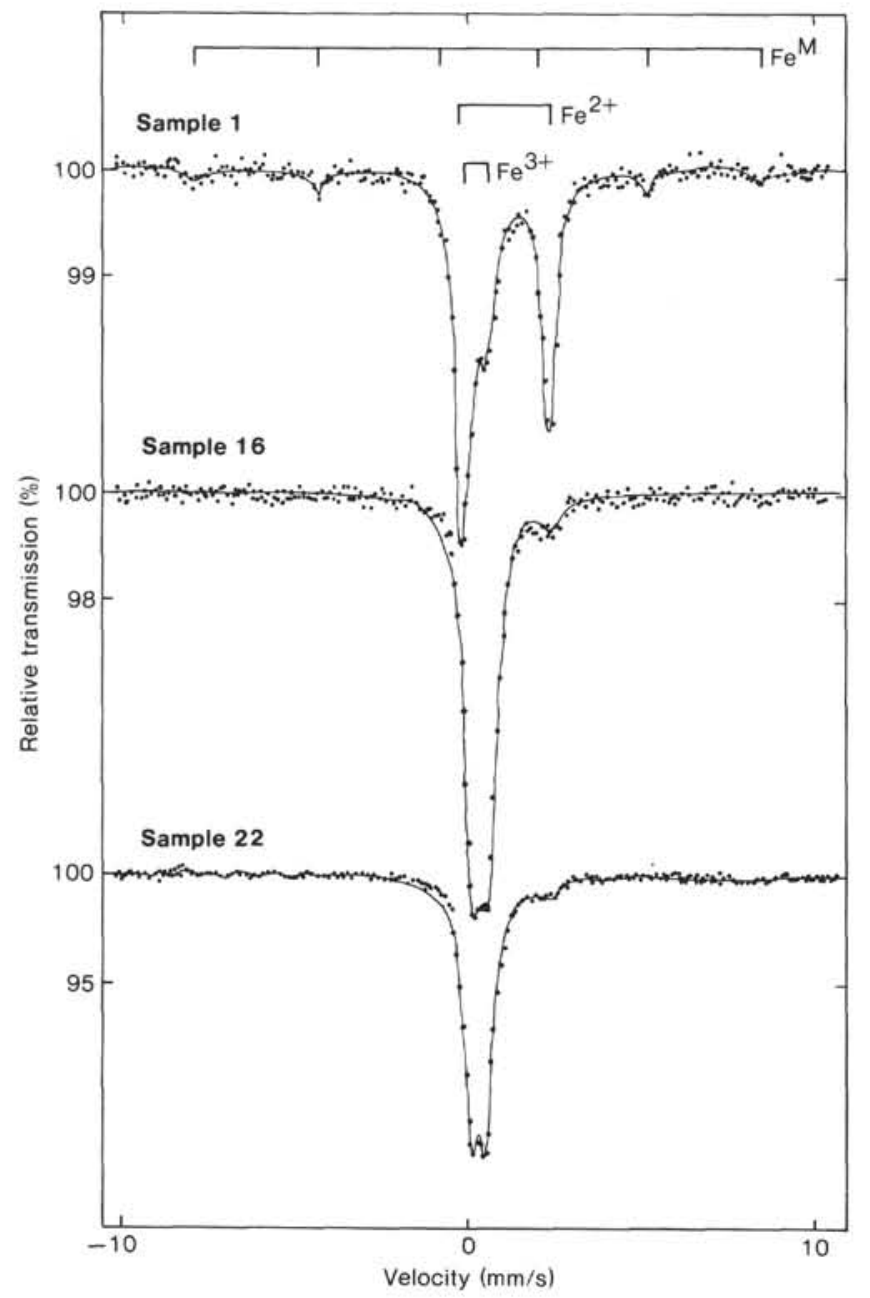

Figure 1. Mössbauer spectra of muds from Units IA and IB.

are the mean values of the $\mathrm{Fe}^{2+}$ and $\mathrm{Fe}^{3+}$ components because of the multiphase nature of the sediments. Therefore, changes in the Mössbauer parameters reflect variations in the amount of the major iron-bearing minerals. Small amounts of other iron-bearing species negligible in the Mössbauer spectra may exist in the sample.

In Unit I, five samples were analyzed with Mössbauer spectroscopy. The Pleistocene dark gray mud (Sample 1) has a spectrum composed of high-spin, paramagnetic $\mathrm{Fe}^{2+}, \mathrm{Fe}^{3+}$, and minor MHFS (Fig. 1). About half of the iron in the mud is $\mathrm{Fe}^{2+}$, if we assume equal recoilfree fractions for all iron-bearing components. The $\mathrm{Fe}^{2+}$ component is characterized by its large quadrupole splitting $(\mathrm{Q}$. S. $=2.59 \mathrm{~mm} / \mathrm{s})$. Our previous study of oceanic sediments (Minai et al., 1981) showed that samples with such large amounts of high-spin $\mathrm{Fe}^{2+}$ were found in regions where terrigenous materials were significant and the sedimentation rate was high. The Mössbauer spectra of samples from such regions (e.g., the Japan Trench) are similar to the spectrum for Sample 1. Because the sedimentation rate at Site 612 was greater than $80 \mathrm{~cm} / 10^{3}$ yr. in the Pleistocene, despite the low amounts of biogenic components (Site 612 chapter, this volume), terrigenous materials were the main source of this mud.
Table 3. Mössbauer parameters of 15 sediment samples from Site 612.

\begin{tabular}{|c|c|c|c|c|c|c|c|}
\hline $\begin{array}{l}\text { Sample } \\
\text { number }\end{array}$ & $\chi^{2} / \mathrm{ch}^{\mathrm{a}}$ & $\begin{array}{c}\mathrm{Fe} \\
\text { species }\end{array}$ & $\underset{(\mathrm{Im} / \mathrm{s})}{\mathrm{I} . \mathrm{S}}$ & $\underset{(\mathrm{mm} / \mathrm{s})}{\mathrm{Q} . \mathrm{S}}$ & $\underset{(\mathrm{mm} / \mathrm{s})}{\mathrm{W}}$ & $\begin{array}{c}\mathrm{H}^{\mathrm{b}} \\
(\mathrm{kG})\end{array}$ & $\begin{array}{c}\text { Relative } \\
\text { area } \\
(\%)\end{array}$ \\
\hline \multirow[t]{3}{*}{1} & \multirow[t]{3}{*}{1.44} & $\mathrm{Fe}^{3+}$ & 0.38 (1) & 0.61 (2) & $0.66(3)$ & & $43(3)$ \\
\hline & & $\mathrm{Fe}^{2+}$ & 1.15 (1) & 2.59 (1) & 0.45 (1) & & $52(3)$ \\
\hline & & $\mathrm{Fe}^{\mathrm{M}}$ & 0.42 (3) & $-0.16(6)$ & $0.3-0.4$ & $510(3)$ & $5(2)$ \\
\hline \multirow[t]{2}{*}{13} & \multirow[t]{2}{*}{ 4.11 } & $\mathrm{Fe}^{3+}$ & 0.32 (1) & 0.51 (1) & 0.57 (1) & & 90 (2) \\
\hline & & $\mathrm{Fe}^{2+}$ & 1.35 (1) & 2.08 (2) & $0.42(4)$ & & 10 (1) \\
\hline \multirow[t]{2}{*}{16} & \multirow{2}{*}{1.90} & $\mathrm{Fe}^{3+}$ & 0.35 (1) & 0.48 (1) & 0.57 (1) & & $92(3)$ \\
\hline & & $\mathrm{Fe}^{2+}$ & 1.36 (2) & 2.06 (4) & $0.42(7)$ & & $8(2)$ \\
\hline \multirow[t]{2}{*}{22} & \multirow[t]{2}{*}{3.95} & $\mathrm{Fe}^{3+}$ & 0.34 (1) & 0.46 (1) & 0.54 (1) & & $95(2)$ \\
\hline & & $\mathrm{Fe}^{2+}$ & 1.13 (1) & $2.46(3)$ & 0.28 (4) & & 5 (1) \\
\hline \multirow[t]{2}{*}{30} & \multirow{2}{*}{1.00} & $\mathrm{Fe}^{3+}$ & 0.31 (1) & 0.51 (1) & 0.51 (1) & & $90(6)$ \\
\hline & & $\mathrm{Fe}^{2+}$ & $1.43(7)$ & 2.1 (1) & 0.6 (2) & & $10(4)$ \\
\hline \multirow[t]{2}{*}{33} & \multirow[t]{2}{*}{1.52} & $\mathrm{Fe}^{3+}$ & 0.33 (1) & 0.51 (1) & 0.47 (1) & & 91 (3) \\
\hline & & $\mathrm{Fe}^{2}$ & 1.15 (2) & 2.69 (4) & 0.39 (6) & & 9 (1) \\
\hline 50 & 0.93 & $\mathrm{Fe}^{3+}$ & 0.32 (1) & $0.51(2)$ & $0.49-0.54$ & & 100 \\
\hline & & $\mathrm{Fe}^{3+}$ & 0.28 (2) & 0.55 (3) & 0.67 (7) & & 100 \\
\hline \multirow{2}{*}{$\begin{array}{l}51 \\
64\end{array}$} & \multirow[t]{2}{*}{2.} & $\mathrm{Fe}^{3+}$ & 0.32 (1) & 0.55 (2) & 0.51 (2) & & $73(7)$ \\
\hline & & $\mathrm{Fe}^{2+}$ & 1.35 (7) & 1.7 (1) & 0.9 (1) & & 27 (6) \\
\hline \multirow{2}{*}{68} & \multirow{2}{*}{1.56} & $\mathrm{Fe}^{3+}$ & 0.28 (1) & 0.50 (2) & $0.50(3)$ & & 82 (11) \\
\hline & & & $1.4(2)$ & $1.6(4)$ & $0.9(3)$ & & $18(9)$ \\
\hline \multirow[t]{2}{*}{82} & \multirow[t]{2}{*}{2.93} & $\mathrm{Fe}^{3}$ & 0.33 (2) & $0.54(5)$ & $0.54(5)$ & & 83 (16) \\
\hline & & & 1.4 (1) & $2.4(2)$ & $0.6(3)$ & & 17 (12) \\
\hline \multirow[t]{2}{*}{100} & \multirow{2}{*}{2.52} & $\mathrm{Fe}^{3+}$ & 0.28 (2) & 0.53 (5) & $0.68(7)$ & & $70(13)$ \\
\hline & & & 1.29 & 1.6 (1) & 0.5 & & 30 (6) \\
\hline \multirow[t]{2}{*}{111} & \multirow{2}{*}{2.45} & & 0.25 & 0.45 & 0.57 & & $73(6)$ \\
\hline & & & 1.41 (2) & 1.59 (3) & $0.52(4)$ & & $27(3)$ \\
\hline \multirow{2}{*}{119} & \multirow[t]{2}{*}{1.91} & & 0.28 (1) & 0.58 (1) & 0.43 (1) & & 84 (5) \\
\hline & & & $1.42(6)$ & $2.2(1)$ & 0.9 (2) & & $16(4)$ \\
\hline & \multirow{2}{*}{1.56} & & 0.34 (1) & $0.58(2)$ & $0.52(3)$ & & 80 (3) \\
\hline & & $\mathrm{Fe}^{2+}$ & 1.15 (1) & 2.62 (1) & 0.58 (1) & & 20 (1) \\
\hline
\end{tabular}

Note: Figures in parentheses in the last five columns denote standard deviations.

a $x^{2}$ divided by channel number.

b ${ }_{\mathrm{H}}$ means internal magnetic field at ${ }^{57} \mathrm{Fe}$ nucleus.

A pattern like that in Figure 1 might be typical of iron distribution in terrigenous materials.

In the Pliocene the sedimentation rate was lower than in the Pleistocene. Spectra from Samples 13, 16, and 22 (Fig. 1) are obviously distinguishable by the high intensity of paramagnetic $\mathrm{Fe}^{3+}$ absorption, lack of MHFS, and the low intensity of $\mathrm{Fe}^{2+}$ absorption. In terms of lithology, this layer is characterized by the presence of glauconite sand (glauconite is an authigenic Fe-bearing mineral). The spectra observed in the Pliocene mud may be ascribed in part to $\mathrm{Fe}^{3+}$ and $\mathrm{Fe}^{2+}$ in glauconite. However, similar amounts of quartz are also known to be present in this layer (Site 612 chapter, this volume). Inasmuch as quartz seems to be supplied as terrigenous clastics, a similar terrigenous supply can be expected in the Pliocene. If we assume that the iron species in the terrigenous materials in the Pliocene muds are the same as those in the Pleistocene mud, and also assume that most of the iron in glauconite is present as $\mathrm{Fe}^{3+}$, then about $30 \%$ of the iron is evaluated as being distributed in terrigenous clastics, and the remaining $70 \%$ of the iron is in glauconite. The high iron content observed in Samples 16 and 22 (Table 2) may be explained by assuming such iron distribution in glauconite and terrigenous clay. Smear slide observation showed a 2:1 glauconite-to-clay ratio in the Pliocene mud layer (Site 612 chapter, this volume). It can be inferred that one and one-half to twice as much iron can be present in glauconite as in clay. This estimate is consistent with our estimate of the iron distribution in the Pliocene muds.

In Sample 30 (Unit II), the carbonate content increases more than 10 times relative to the overlying sediments (Table 2). In Unit II, large amounts of siliceous 
fossils were also observed (Site 612 chapter, this volume). The spectra of ooze Samples 30 (Fig. 2) and 33 are similar to those of the Pliocene muds (Samples 13, 16, and 22; Fig. 1). Glauconite is continuously found through the upper Eocene. The interpretation of the Mössbauer spectra of the Pliocene muds also applies to Samples 30 and 33 , in spite of the dilution of the latter with siliceous fossils and carbonates.

For the middle Eocene chalks (Samples 50 [Fig. 2] and 51), the $\mathrm{Fe}^{2+}$ components in the spectra disappeared. The abundance of siliceous fossils, the high carbonate content (Table 2), and the disappearance of quartz strongly suggest that these chalks are mainly composed of biogenic materials. The iron in the chalks was mainly supplied by biogenic or hydrogenous materials coprecipitated with or adsorbed by biogenic particles. The Mössbauer spectra of typical pelagic clays are mostly composed of paramagnetic $\mathrm{Fe}^{3+}$ quadrupole doublets (Minai et al., 1981; Thijs et al., 1981). The spectra for Samples 50 and 51 may be typical of biogenic or hydrogenous sediments.

The lowermost part of the middle Eocene chalk (Sample 64 at the boundary between Units II and III) and the lower Eocene chalks (Samples 68, 82, and 100, in Unit III) contain high-spin $\mathrm{Fe}^{2+}$ (Figs. 2 and 3). The Mössbauer parameters of these $\mathrm{Fe}^{2+}$ components are distinguishable from the values of $\mathrm{Fe}^{2+}$ in the Pliocene and Pleistocene sediments (Table 3). This means that different components of $\mathrm{Fe}^{2+}$-bearing phases are mainly included in the Unit II and the lowermost Unit III chalks. The reported values of I. S. and Q. S. for siderite (I. S.

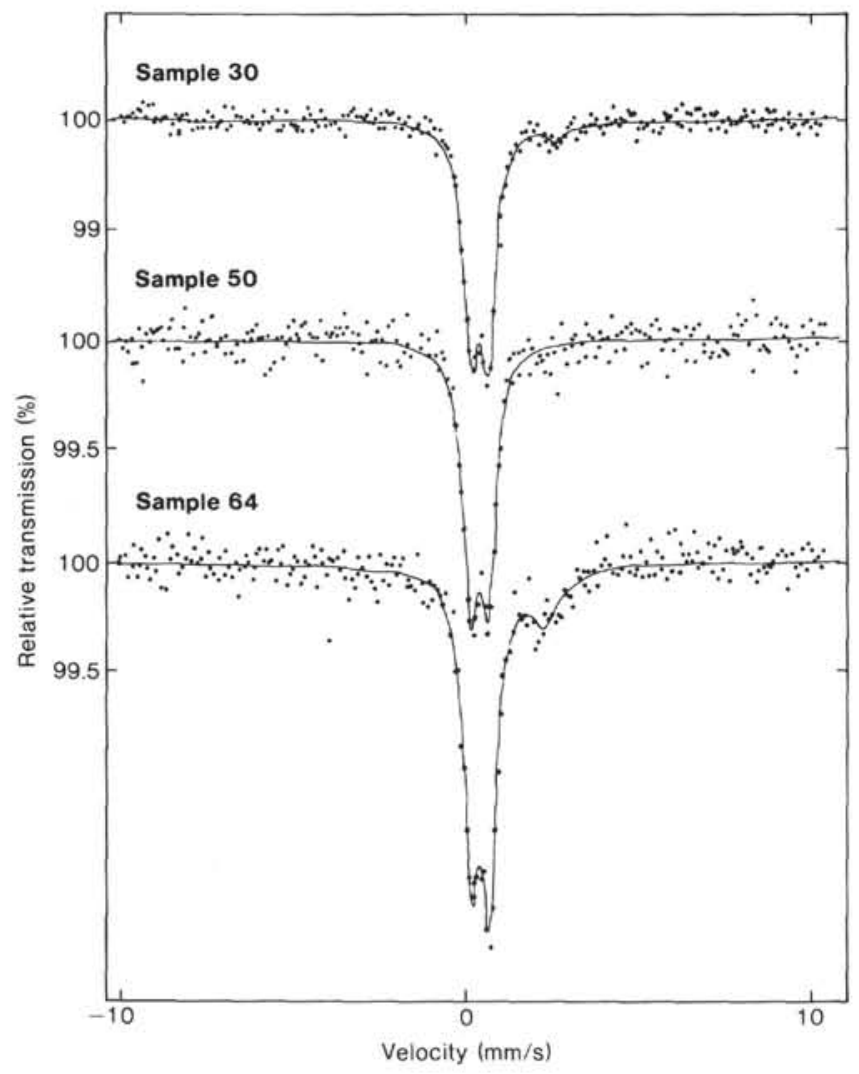

Figure 2. Mössbauer spectra of oozes from Unit IC and chalks from Unit II.
$=1.239 \mathrm{~mm} / \mathrm{s}$ and Q. S. $=1.798 \mathrm{~mm} / \mathrm{s}$; Ono and Ito, 1964) are similar to our parameters for the $\mathrm{Fe}^{2+}$ component in Unit III. The slight discrepancy between reported Mössbauer parameters and ours means that the $\mathrm{Fe}^{2+}$ is not in "pure" siderite in the chalks, but rather is substituting in $\mathrm{Ca}$ or $\mathrm{Mg}$ sites in carbonates. In many cases the Mössbauer parameters are sensitive to such cation substitution in solids (Greenwood and Gibb, 1971). A recent Mössbauer study (Mørup et al., 1985) reported that Mössbauer parameters (I. S. $=1.21$ to $1.30 \mathrm{~mm} / \mathrm{s}$, Q. S. $=1.40$ to $1.65 \mathrm{~mm} / \mathrm{s}$ ) for ankerite, ferroan dolomite, or $\mathrm{Fe}^{2+}$ in calcite were very similar to ours. Such resemblance in the parameters strongly suggests that $\mathrm{Fe}^{2+}$ substitutes for the $\mathrm{Ca}$ or $\mathrm{Mg}$ site in the carbonates. In the lower Eocene layers, the siliceous fossils are less abundant, whereas the amount of carbonate is similar to that in Unit II (Site 612 chapter, this volume). With the dissolution of silica after burial, the accompanying iron was readsorbed into carbonates. The discrepancy between the Mössbauer spectra of the chalks in Units II and III may be accounted for by the relatively large amounts of iron accompanying the carbonate in Unit III. The adsorbed or coprecipitated iron on carbonate surfaces may replace $\mathrm{Ca}$ or $\mathrm{Mg}$ at the divalent-cation site after burial, whereas the iron accompanied by silica may exist as ferric gel or silicate clay. Further study of the formation of $\mathrm{Fe}^{2+}$-substituted carbonates in sediments is needed.

In Unit IV, the Mössbauer spectrum of Sample 111 (Fig. 4) is similar to the spectra of the lower Eocene chalks, whereas the spectrum of the chalk in Sample

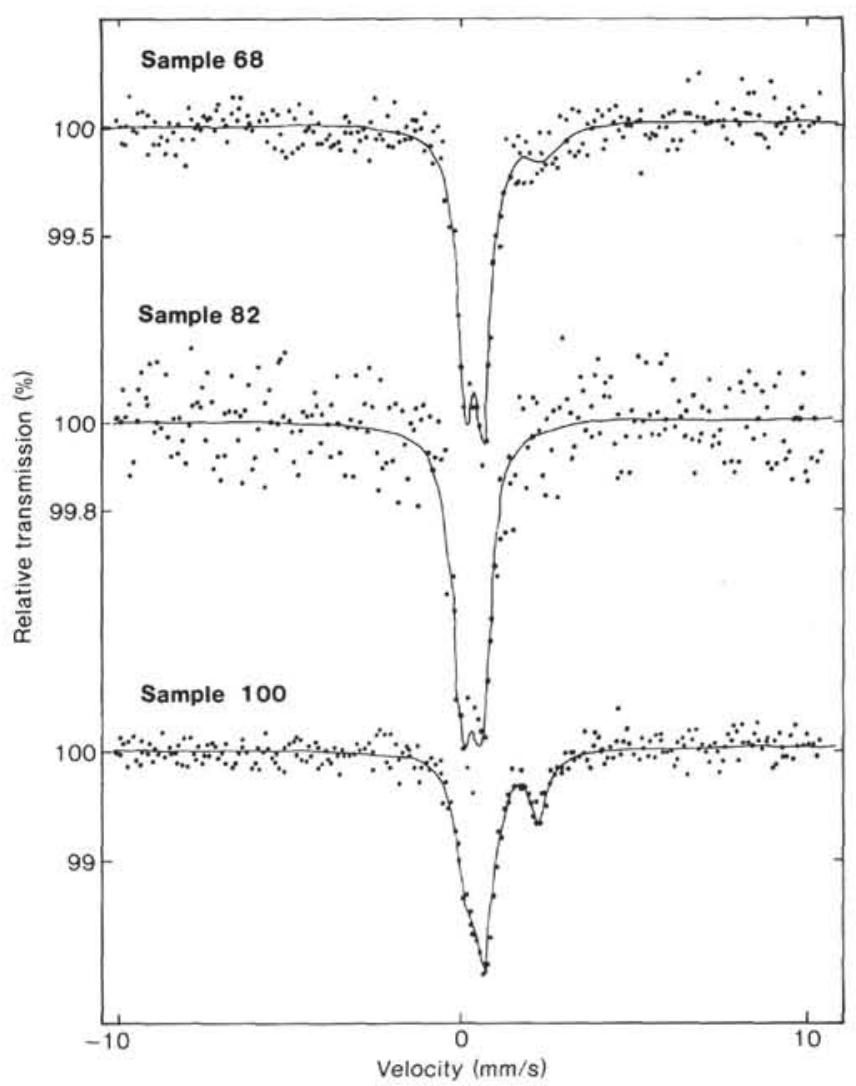

Figure 3. Mössbauer spectra of chalks from Unit III. 


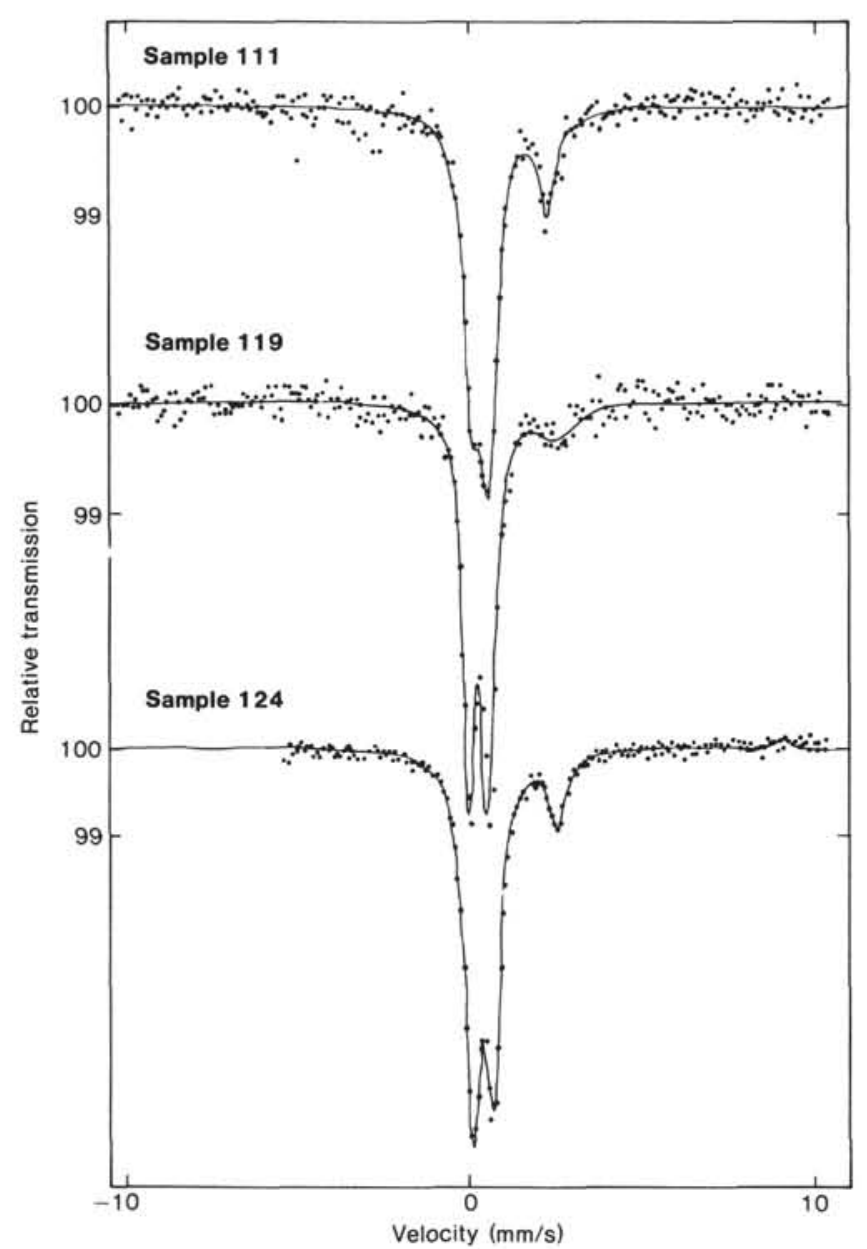

Figure 4. Mössbauer spectra of chalks from Unit IV and a shale from Unit V.

119 has a different $\mathrm{Fe}^{2+}$ component. The upper Campanian shale (Sample 124) has terrigenous $\mathrm{Fe}^{2+}$ parameters similar to those of Sample 1 . From this $\mathrm{Fe}^{2+}$ component we can infer that in the Campanian the terrigenous fraction incorporates about $40 \%$ total iron, assuming that the spectrum for terrigenous matter consists of the $\mathrm{Fe}^{2+}$ component with about $1.1 \mathrm{~mm} / \mathrm{s}$ of I. S., $2.6 \mathrm{~mm} / \mathrm{s}$ of Q. S., and an equal amount of $\mathrm{Fe}^{3+}$ component. The Q. S. for Sample 119 in Unit IV is midway between the terrigenous $\mathrm{Fe}^{2+}$ in sample 124 and the carbonate $\mathrm{Fe}^{2+}$ in Sample 111. In addition, the linewidth for $\mathrm{Fe}^{2+}$ is significantly larger. This result suggests that the $\mathrm{Fe}^{2+}$ component in the Maestrichtian chalk is a mixture of the terrigenous and carbonate $\mathrm{Fe}^{2+}$. The variation of the Mössbauer parameters suggests that Unit IV can be characterized as a transition layer between the upper Campanian (Unit V) and the lower Eocene (Unit III) layers.

For a more precise discussion of iron geochemistry in the sedimentation process, we need more geochemical data (including Mössbauer results) and information about mineralogy, physical properties, sedimentation rates, and other geological information for many sites in various sedimentation environments.

\section{CONCLUSIONS}

We base the following conclusions on Mössbauer data:

1. Iron in the sediment column from Site 612 is present as paramagnetic high-spin $\mathrm{Fe}^{3+}$ and $\mathrm{Fe}^{2+}$ and MHFS $\left(\mathrm{Fe}^{\mathrm{M}}\right)$ components.

2. The Mössbauer parameters especially for high-spin $\mathrm{Fe}^{2+}$, depend on the sub-bottom depth of the sample, a relationship that suggests that the main $\mathrm{Fe}^{2+}$ species in the sediment column varies with depth.

3. The Mössbauer parameters suggest that the $\mathrm{Fe}^{2+}$ in the sediment is the species included in terrigenous clay and $\mathrm{Fe}^{2+}$-bearing carbonates. The $\mathrm{Fe}^{3+}$ is identified as those species included in terrigenous clay, glauconite, and hydrogenous ferric gel, and the $\mathrm{Fe}^{\mathrm{M}}$ is identified as titanomaghemite.

4. The lithologic units identified in the section correspond to the vertical variation of chemical states of iron as reflected in Mössbauer parameters and peak area ratios.

\section{REFERENCES}

Bancroft, G. M., 1973. Mössbauer Spectroscopy: An Introduction for Inorganic Chemists and Geochemists: London (McGraw-Hill).

Bancroft, G. M., Burns, R. G., and Stone, A. J., 1968. Applications of the Mössbauer effect to silicate mineralogy-II. Iron silicates of unknown and complex crystal structures. Geochim. Cosmochim. Acta., 32:547-559.

Bancroft, G. M., Maddock, A. G., and Burns, R. G., 1967. Applications of the Mössbauer effect to silicate mineralogy-I. Iron silicates of known crystal structure. Geochim. Cosmochim. Acta., 31: 2219-2246.

Bowen, L. H., and Weed, S. B., 1984. Mössbauer spectroscopy of soils and sediments. In Herber, R. H. (Ed.), Chemical Mössbauer Spectroscopy: New York (Plenum), pp. 217-242.

Duke, B. J., and Gibb, T. C., 1967. Numerical estimation of Mössbauer spectra parameters. J. Chem. Soc. A, 1478-1483.

Greenwood, N. N., and Gibb, T. C., 1971. Mössbauer Spectroscopy: London (Chapman and Hall).

Herzenberg, C. L., 1970. Mössbauer spectrometry as an instrumental technique for determinative mineralogy. In Gruverman, I. J. (Ed.), Mössbauer Effect Methodology (Vol. 5): New York (Plenum), 209230.

Jensen, S. D., and Shive, P. N., 1973. Cation distribution in sintered titanomagnetites. J. Geophys. Res., 78:8474-8480.

Minai, Y., Furuta, T., Kobayashi, K., and Tominaga, T., 1981. A Mössbauer study of deep sea sediments. Radiochem. Radioanal. Lett., 48:165-174.

Mørup, S., Franck, J., Wonterghem, J. van, Roy-Poulsen, H., and Larsen, L., 1985. Mössbauer spectroscopy study of the chemical state of iron in Danish Mesozoic sediments. Fuel, 64:528-539.

Ono, K., and Ito, A., 1964. Mössbauer study of magnetic properties in ferrous compounds. J. Phys. Soc. Jpn., 19:899-907.

Thijs, A., De Roy, G., Vansant, E. F., Glasby, G. P., and Thijssen, T., 1981. Mössbauer effect studies of iron in manganese nodules and associated marine sediments in five areas in the equatorial and S. W. Pacific. Geochem. J., 15:25-37.

Tominaga, T., and Minai, Y., 1984. Applications of Mössbauer spectroscopy to environmental and geochemical studies. Nucl. Sci. Appl., 1:749-791.

Watt, J. P., Leiper, W., Ade-Hall, J. M., and Goble, D. F., 1973. Measurements of $\mathrm{Fe}^{3+} / \mathrm{Fe}^{2+}$ ratios in basaltic class I titanomagnetites using the Mössbauer effect. J. Geophys. Res., 78:3301-3309.

Date of Initial Receipt: 3 June 1985

Date of Acceptance: 3 January 1986 